\title{
Membina Kerelasian Nasabah Bank BPR Di Kota Pekanbaru
}

\author{
ARMAN \\ Sekolah Tinggi Ilmu Ekonomi Bangkinang \\ Jl. Dr. A Rahman Saleh, Bangkinang, Kabupaten Kampar, No. 54, Riau 28463 \\ E-mail : arman@lecturer.stie.bangkinang.ac.id
}

\begin{abstract}
Pekanbaru City is one of the developing cities, where the current development of banking is also very rapid. One of them is a BPR bank. Competition between conventional banks coupled with Islamic banks greatly made BPR banks continue to make improvements. Especially in order to safeguard its customers. One of the efforts to look after these customers is to foster reluctance with them. Through a descriptive approach and survey to $50 \mathrm{BPR}$ customers in Pekanbaru City. The results of the study show that rural banks in the city of Pekanbaru are very varied, where the category of service delivery flexibility is not good towards very good. Therefore, there is still a need for better and more equitable marketing efforts. Efforts can be made in fostering the marketing of BPR products by providing means to accommodate customer suggestions, then discussing with customers, also providing an explanation of work processes and procedures for BPRs, as well as efforts to build closer relationships with customers through the provision of online information systems. Then in terms of BPR officers in building relationships with customers it is necessary to increase their sense of responsibility, to resolve customer problems thoroughly by providing training to officers.
\end{abstract}

Keywords: Fostering, Customer Relationship, BPR Bank

Bank Perkreditan Rakyat (BPR) adalah lembaga keuangan bank yang menerima simpanan hanya dalam bentuk deposito berjangka, tabungan, dan/atau bentuk lainnya yang dipersamakan dan menyalurkan dana sebagai usaha BPR. Dengan lokasi yang pada umumnya dekat dengan tempat masyarakat yang membutuhkan.

Usaha BPR meliputi usaha untuk menghimpun dan menyalurkan dana dengan tujuan mendapatkan keuntungan. Keuntungan BPR diperoleh dari spread effect dan pendapatan bunga. Adapun usaha-usaha BPR adalah: Menghimpun dana dari masyarakat dalam bentuk simpanan berupa deposito berjangka, tabungan, dan/atau bentuk lainnya yang dipersamakan dengan itu; Memberikan kredit; Menyediakan pembiayaan bagi nasabah berdasarkan prinsip bagi hasil sesuai dengan ketentuan yang ditetapkan dalam Peraturan Pemerintah; Menempatkan dananya dalam bentuk Sertifikat Bank
Indonesia (SBI), deposito berjangka, sertifikat deposito, dan/atau tabungan pada bank lain. SBI adalah sertifikat yang ditawarkan Bank Indonesia kepada BPR apabila BPR mengalami over liquidity atau kelebihan likuiditas.

Kota Pekanbaru merupakan salah satu kota yang berkembang, dimana saat ini perkembangan perbankan juga sangat pesat. Salah satunya adalah bank BPR. Persaingan antara bank konvensional ditambah dengan bank syariah sangat membuat bank BPR menjadi terus melakukan perbaikan. Khususnya dalam rangka menjaga nasabahnya. Usaha menjaga nasabah ini salah satunya adalah dengan membina kerelasian dengan mereka.

Konsep berkenaan dengan pemasaran kerelasian telah berkembang menjadi suatu paradigma baru bagi perusahaan di dalam menciptakan kedekatan hubungan antara perusahaan dengan pelanggan. Kedekatan perusahaan 
dengan pelanggan dimaksudkan agar pelanggan tetap atau lebih loyal, tetap mengkonsumsi produk atau jasa perusahaan, dan memerlukan pemenuhan produk atau jasa yang diperlukan. Oleh sebab itu, perusahaan menentukan pasar sasaran dengan tetap serta mengemas produknya untuk ditawarkan kepada pelanggan dan calon pelanggan. Adapun pengertian pemasaran kerelasian menurut Gronros dalam Tatang (2010:78) yaitu “ satisfied customer may become commited to the supplier or service provider, because they trust the other party or are pleased with the level or sacriffe involved in the relationship. Customer satisfaction also contributes to the formation of bonds between the two parties."

Relationship Marketing (Kerelasian Pemasaran) sangat relevan untuk dibahas dalam pemasaran jasa, mengingat keterlibatan dan interaksi antara pelanggan dan pemberi jasa begitu tinggi pada sebagian besar bisnis jasa. Menurut Lupiyoadi (2006: 72), "Pendekatan transactional marketing (pemasaran yang hanya berorientasi pada transaksi) dengan sasaran penjualan yang tinggi dalam jangka pendek menjadi kurang mendukung pada praktik bisnis jasa, pendekatan yang lebih tepat digunakan adalah pendekatan relationship marketing. Relationship marketing merupakan suatu pendekatan yang menekankan pada usaha menarik dan mempertahankan pelanggan melalui peningkatan hubungan perusahaan dengan pelanggannya".Relationship marketing adalah cara usaha pemasaran pada pelanggan yang meningkatkan pertumbuhan jangka panjang perusahaan dan kepuasan maksimum pelanggan. Pelanggan yang baik merupakan suatu asset di mana bila ditangani dan dilayani dengan baik akan memberikan pendapatan dan pertumbuhan jangka panjang bagi suatu perusahaan.

Kerelasian pemasaran menurut Tandjung (2004: 89) bahwa, "Relationship marketing adalah pertumbuhan, pengembangan, dan pemeliharaan dalam jangka panjang yang menimbulkan hubungan biaya efektif dengan pelanggan, pemasok, karyawan, dan partner-partner lain yang saling menguntungkan". Relationship marketing merupakan suatu praktik membangun hubungan jangka panjang yang memuaskan dengan pihak-pihak kunci meliputi pelanggan, pemasok, dan penyalur guna mempertahankan preferensi bisnis dalam jangka panjang.

$$
\text { Menurut Chan (2003: 87), }
$$

"Relationship marketing ditujukan untuk menciptakan pengenalan bagi setiap pelanggan secara lebih dekat melalui komunikasi dua arah dengan mengelola suatu hubungan yang saling menguntungkan antara pelanggan dan perusahaan".

Relationship marketing merupakan upaya pengenalan kepada setiap pelanggan secara lebih dekat, menciptakan komunikasi dua arah dengan konsumen, dan mengelola hubungan yang saling antara pelanggan dan konsumen. Relationship marketing merupakan konsep yang dinamis, perilaku pelanggan yang merupakan komponen utama untuk menentukan arah kebijakan relationship marketing dari waktu ke waktu selalu berubah.

Relationship marketing merupakan interaksi yang penting dalam menjalankan sebuah bisnis. Sebagaimana yang diungkapkan Ford dalam Imron (2011) bahwa, "Relationship as the pattern of interactions and the mutual conditioning of behaviors over time, between company and a customer, a supplier or another organization". Maksudnya, pola interaksi dan kondisi yang menguntungkan antara perusahaan dan konsumen, pemasok, atau organisasi lainnya.

Definisi di atas menekankan bahwa kerelasian pemasaran memberikan perhatian terhadap transaksi yang sedang berlangsung, memantapkan, memelihara dan memperkuat hubungan dengan pelanggan sebagai dasar untuk hubungan berkelanjutan, yang sejalan dengan 
pendapat Morgan dan Hunt dalam Kusmayadi, Tatang (2007: 79) yang mengemukakan bahwa relationship marketing refers to all marketing activities directed toward estabilishing, developing and maintanining succesfull relational exchange.

Adapun karakteristik-karakteristik dari pemasaran kerelasian (Relationship Marketing) menurut Sheth dalam Harun (2011: 59) adalah :It relates to one-to-one relationship between the marketer and the customer; It occurs as an interactive process and not as a tranxactional exchange; Unique aspect of customer relationship management is that it is a value added activity through mutual, interdepence and collaboration between suppliers and customers. Maksudnya konsep kerelasian pemasaran tersebut di atas membahas masalah satu-ke-satu hubungan antara pemasar dan pelanggan; Hal ini terjadi sebagai proses interaktif dan bukan sebagai pertukaran tranxactional; Aspek unik dari manajemen hubungan pelanggan adalah bahwa itu adalah nilai tambah kegiatan melalui saling, interdepence dan kolaborasi antara pemasok dan pelanggan)

Pemasaran kerelasian pelanggan (customer relationship marketing) merupakan sebuah bentuk pemasaran dimana perusahaan mempunyai target dalam pelanggan dan membuat komunikasi pemasaran yang relevan (Butz Goodstein dalam Isnadi, 2005:34). Gronroos dalam Putra (2009:87) menyatakan: "Satisfied customers may became committed to the supplier or service provider, because they trust the other party or are pleased with the level of sacriffce involved in the relationship. Customer satisfaction also contributes to the formation of bonds between the two parties."

Evans dan Laskin dalam Isnadi (2005) menyatakan bahwa customer relationship marketing terdiri dari beberapa dimensi, yaitu understanding customer expectation, building service partnership, total quality management, dan empowering employees. 1). Understanding Customer Expectation. Understanding customer expectation merupakan upaya perusahaan dalam melakukan identifikasi apa yang diinginkan oleh konsumen dan memasarkan barang dan jasa diatas tingkat yang konsumen harapkan. Indikator dari variabel ini adalah: a. Keamanan dari produk yang ditawarkan. b. Produk sesuai dengan apa yang diharapkan. c. Produk dapat menjaga mesin dengan baik. 2). Building Service Partnership. Building service partnership merupakan kerjasama yang dilakukan oleh perusahaan dengan konsumen dalam menambahkan pelayanan yang diinginkan oleh konsumen atas suatu produk perusahaan. Indikator dari variabel ini adalah: a. Kemampuan perusahaan mendengarkan dan mengatasi keluhan pelanggan. b. Kemampuan perusahaan dalam melibatkan pelanggan untuk meningkatkan mutu. c. Kemampuan perusahaan dalam menjalin komunikasi dengan konsumen. 3). Total Quality Management. Total quality management merupakan suatu usaha membangun mutu perusahaan secara terpadu yang memacu seluruh organisasi, mulai dari pemasok sampai pada konsumen (Lilik Afi W dalam Isnadi (2005). Indikator dari variabel ini adalah : a. Kemampuan perusahaan dalam memproduksi produk yang aman. b. Kemampuan perusahaan dalam memproduksi produk yang berkualitas. c. Kemampuan perusahaan dalam memproduksi produk yang ramah lingkungan. 4). Empowering Employees. Empowering employees merupakan upaya pemberdayaan yang dilakukan oleh perusahaan kepada karyawannya untuk berusaha memenuhi kebutuhan konsumen dan menyelesaikan permasalahan konsumen. Indikator dari variabel ini adalah: a. Tanggung jawab karyawan dalam menyelesaikan masalah. b. Kemampuan perusahaan dalam menyediakan lingkungan dan suasana kerja yang baik bagi karyawan. c. 
Kemampuan karyawan dalam menyelesaikan masalah.

Tjiptono (2014: 433) dimensi kerelasian pemasaran adalah financial; social; customization dan structural bonds. Alma (2014: 271) relationship marketing merupakan upaya mengenal konsumen lebih baik, sehingga perusahaan dapat memenuhi needs dan want mereka. Dimensinya: strategi organisasi, interaksi, teknologi dan proses bisnis. Kotler and Keller (2012: 189) dimensi kerelasian marketing yaitu: menarik, mempertahankan dan menumbuhkan pelanggan.

Kerelasian pemasaran menurut Tjiptono (2014: 433); Alma (2014: 271); Kotler and Keller (2012: 189) dapat disintesakan sebagai usaha menjaga hubungan dengan pelanggan melalui:proses interaktif; nilai tambah dan interdepence. Dari pendapat di atas, maka dapat disimpulkan bahwa kerelasian pemasaran adalah strategi yang komprehensif dan proses, memperoleh, mempertahankan, dan partneris dengan pelanggan selektif untuk menciptakan nilai superior bagi perusahaan dan pelanggan. Indikatornya: Hal ini terkait dengan satu kesatuan hubungan antara pemasar dan pelanggan: Proses interaktif dan bukan sebagai pertukaran transaksional; Aspek unik dari manajemen hubungan pelanggan adalah nilai tambah kegiatan melalui selling; Interdependence dan kolaborasi antara pemasok dan pelanggan.

\section{METODE}

Jenis penelitian yang digunakan dalam penelitian ini adalah penelitian menggunakan pendekatan survey. Survey kepada nasabah Bank BPR di Kota Pekanbaru yakni kepada nasabah sebanyak 50 orang sampel. Data dikumpulkan dengan menggunakan kuesioner.

Membina relasi dengan nasabah bank BPR adalah strategi yang komprehensif dan prosess, memperoleh, mempertahankan, dan partneris dengan pelanggan selektif untuk menciptakan nilai superior bagi perusahaan dan pelanggan. Indikatornya: Hal ini terkait dengan satu-ke-satu hubungan antara pemasar dan pelanggan:

a. Proses interaktif dan bukan sebagai pertukaran tranxactional

b. Aspek unik dari manajemen hubungan pelanggan adalah bahwa itu adalah nilai tambah kegiatan melalui selling

c. Interdependence dan kolaborasi antara pemasok dan pelanggan.

Untuk melihat lebih detail operasionalisasi variabel membangun relasi kepada nasabah bank BPR sebagai berikut:

Tabel 1: Operasionalisasi Variabel Membina Relasi Nasabah Bank BPR

\begin{tabular}{|c|c|c|}
\hline Dimensi & Indikator & Ukuran \\
\hline \multirow{6}{*}{$\begin{array}{lr}1 . \quad \text { proses } & \text { interaktif, } \\
\text { membangun } & \text { hubungan } \\
\text { interaktif } & \text { antara } \\
\text { pelanggan } & \text { dengan } \\
\text { penyedia layanan }\end{array}$} & $\begin{array}{ll}\text { Ketersediaan } & \\
\text { menerima } & \text { kritik } \\
\text { pelanggan BPR } & \end{array}$ & $\begin{array}{l}\text { Tingkat } \\
\text { ketersediaan }\end{array}$ \\
\hline & $\begin{array}{l}\text { Ketersediaan } \\
\text { menampung } \\
\text { pelanggan BPR }\end{array}$ & $\begin{array}{l}\text { Tingkat } \\
\text { ketersediaan }\end{array}$ \\
\hline & $\begin{array}{lr}\text { Bersedia } & \text { berdiskusi } \\
\text { dengan } & \text { pelanggan } \\
\text { BPR } & \text { tentang } \\
\text { permasalahan nya }\end{array}$ & $\begin{array}{l}\text { Tingkat } \\
\text { kesediaan }\end{array}$ \\
\hline & $\begin{array}{l}\text { Menyediakan layanan } \\
\text { telfon dalam proses } \\
\text { pelayanan BPR }\end{array}$ & $\begin{array}{l}\text { Tingkat } \\
\text { kesediaan }\end{array}$ \\
\hline & $\begin{array}{l}\text { Menyediakan layanan } \\
\text { sms banking oleh } \\
\text { petugas BPR }\end{array}$ & $\begin{array}{l}\text { Tingkat } \\
\text { kesediaan }\end{array}$ \\
\hline & $\begin{array}{l}\text { Menyediakan layanan } \\
\text { antar jemput angsuran } \\
\text { kredit oleh petugas } \\
\text { BPR }\end{array}$ & $\begin{array}{l}\text { Tingkat } \\
\text { kesediaan }\end{array}$ \\
\hline \multirow{6}{*}{$\begin{array}{l}\text { 2. hubungan pelanggan, } \\
\text { memberikan nilai } \\
\text { tambah bagi pelanggan } \\
\text { dan penyedia layanan }\end{array}$} & $\begin{array}{ll}\text { Membangun } & \text { Jalinan } \\
\text { komunikasi } & \text { kepada } \\
\text { pelanggan BPR } & \\
\end{array}$ & Tingkat jalinan \\
\hline & $\begin{array}{l}\text { Menyampaikan } \\
\text { informasi yang akurat } \\
\text { oleh petugas BPR }\end{array}$ & $\begin{array}{l}\text { Tingkat } \\
\text { penyampaian }\end{array}$ \\
\hline & $\begin{array}{l}\text { Menjelasakan proses } \\
\text { kerja oleh petugas } \\
\text { BPR kepada } \\
\text { pelanggan BPR }\end{array}$ & $\begin{array}{l}\text { Tingkat } \\
\text { kejelasan }\end{array}$ \\
\hline & $\begin{array}{lr}\text { Menjelaskan } & \text { batas } \\
\text { layanan } & \text { yang } \\
\text { diberikan petugas } & \text { BPR } \\
\end{array}$ & $\begin{array}{l}\text { Tingkat } \\
\text { kejelasan }\end{array}$ \\
\hline & $\begin{array}{lr}\text { Menjalin } & \text { hubungan } \\
\text { pelanggan } & \text { yang } \\
\text { berkesinambun gan }\end{array}$ & Tingkat jalinan \\
\hline & $\begin{array}{lr}\text { Menjaga } & \text { hubungan } \\
\text { harmonis } & \text { dengan } \\
\text { pelanggan } & \text { BPR }\end{array}$ & $\begin{array}{l}\text { Tingkat } \\
\text { keharmonisan }\end{array}$ \\
\hline \multirow{6}{*}{$\begin{array}{l}\text { 3. interdepend- dence, } \\
\text { merupakan kolaborasi } \\
\text { antara pemasok dan } \\
\text { pelanggan }\end{array}$} & $\begin{array}{lr}\text { Terjalin } & \text { kerjasama } \\
\text { antar } & \text { pelanggan } \\
\text { dengan BPR } & \\
\end{array}$ & Tingkat jalinan \\
\hline & \begin{tabular}{ll}
\multicolumn{2}{l}{ Keterlibatan } \\
pelanggan ke BPR \\
dalam & mengambil \\
keputusan &
\end{tabular} & $\begin{array}{l}\text { Tingkat } \\
\text { keterlibatan }\end{array}$ \\
\hline & $\begin{array}{l}\text { Kejelasan tanggung } \\
\text { jawab petugas BPR } \\
\text { kepada pelanggannya }\end{array}$ & $\begin{array}{l}\text { Tingkat } \\
\text { tanggung } \\
\text { jawab }\end{array}$ \\
\hline & $\begin{array}{l}\text { Kondisi suasana kerja } \\
\text { petugas }\end{array}$ & $\begin{array}{l}\text { Tingkat } \\
\text { kenyamanan }\end{array}$ \\
\hline & $\begin{array}{l}\text { Menyelesaikan } \\
\text { masalah yang dihadapi } \\
\text { pelanggan BPR }\end{array}$ & $\begin{array}{l}\text { Tingkat } \\
\text { penyelesaian }\end{array}$ \\
\hline & $\begin{array}{l}\text { Ketuntasan masalah } \\
\text { pelanggan BPR }\end{array}$ & $\begin{array}{l}\text { Tingkat } \\
\text { ketuntasan }\end{array}$ \\
\hline
\end{tabular}


Data yang terkumpul dianalisis secara deskriptif, yakni dengan menggambarkan secara gamblang hasil penelitian yang berkaitan dengan membina kerelasian nasabah bank BPR.

\section{HASIL}

Kerelasian pelanggan adalah strategi yang komprehensif dan prosess, memperoleh, mempertahankan, dan partneris dengan pelanggan selektif untuk menciptakan nilai superior bagi perusahaan dan pelanggan. Kerelasian Pemasaran diukur oleh 18 indikator pertanyaan dengan 3 dimensi yaitu Proses Interaktif, Hubungan Pelanggan dan Interdepence. Berikut ini adalah rekapitulasi hasil tanggapan responden dari 18 indikator pertanyaan yang diajukan untuk mengukur Kerelasian Pemasaran.

Apabila dilihat dari seluruh dimensi, maka dapat diketahui kerelasian pemasaran BPR di Propinsi Riau dengan skor sebesar 3,1262 dengan standar deviasi 0,9695 masuk dalam kategori cukup baik menuju baik, dari 18 indikator penelitian dapat diketahui bahwa indikator tertinggi adalah membangun jalinan komunikasi kepada nasabah BPR dan kondisi suasana kerja petugas.

Sedangkan dua indikator terendah adalah keterlibatan nasabah ke BPR dalam mengambil keputuasan dan menyelesaikan masalah yang dihadapi nasabah BPR.

\section{PEMBAHASAN}

Berdasarkan tabel distribusi frekuensi diatas, dapat disimpulkan bahwa Variabel Kerelasian Pemasaran yang terdiri dari 18 pernyataan dengan rincian frekuensi. Kerelasian Pemasaran memiliki rata-rata 3,1262 dan standar deviasi 0,9220 dinyatakan termasuk kategori cukup baik, hal ini mengindikasikan bahwa BPR di Kota Pekanbaru, sangat bervariatif, dimana katagorinya dari kerelasian pemsaran jasa tidak baik menuju sangat baik. Oleh karena itu masih perlu adanya upaya peningkatan kerelasian pemasaran yang lebih baik lagi dan lebih merata.
Apabila dilihat dari seluruh dimensi, maka dapat diketahui kerelasian pemasaran BPR di Propinsi Riau dengan skor sebesar 3,1262 masuk dalam kategori cukup baik, dari 18 indikator penelitian dapat diketahui bahwa terdapat sebanyak 10 indiaktor yang nilainya di bawah nilai total rata-rata yakni:

1) Kurangnya ketersediaan sarana menampung saran nasabah BPR

2) Kurangnya kesediaan berdiskusi dengan nasabah BPR tentang permaasalahannya

3) Kurangnya penjelaan proses kerja oleh petugas BPR kepada nasabah BPR

4) Kurang terjalin hubungan dengan pelanggan yang berkesinambungan

5) Kurang terjaga hubungan harmonis dengan pelanggan BPR

6) Kurang terjalin kerjasama antar pelanggan dengan BPR

7) Kurang mempertimbangkan masukan pelanggan ke BPR dalam mengambil keputusan.

8) Kurang jelas tanggung jawab petugas BPR kepada nasabahnya

9) Kurangnya kemampuan menyelesaikan masalah yang dihadapi nasabah BPR

10) Kurang tuntas dalam penyelesaian masalah nasabah BPR

Kemudian apabila dilihat dari seuruh dimensi kualitas pelayanan jasa diketahui dimensi tertinggi adalah pada dimensi: Proses interaktif; HUbungan pelanggan. Sedangkan dimensi di bawah nilai total rata-rata adalah Interdependence. Berdasarkan data pada tabel tersebut, maka dapat dikatakan kerelasian pemasaran seluruh dimensi ditanggapi responden dengan skor yang dihasilkan cukup baik $(3,1262)$ dari hal tersebut dimensi tertinggi adalah pada dimensi proses interaktif dimana BPR menerima kritik dari nasabah dan juga menerima layanan telfon dan juga menerima layanan antar jemput angsuran, Sedangkan yang terendah adalah pada dimensi interdependence mengenai dilibatkan nasabah dalam mengambil keputusan dan juga menyelesaikan masalah 
yang dihadapi nasabah.

Hal ini disebabkan dimensi

Interdependence dengan 6 item pertanyaan dengan skor 2,9003, hal ini mengindikasikan bahwa perusahaan selalu dituntut untuk menjalin hubungan yang independen dengan nasabah dan selalu berupaya menjalin hubungan dengan nasabah dalam melakukan keputusan organisasi. Nilai yang paling rendah dari dimensi ini adalah pada pertanyaan "Keterlibatan nasabah ke BPR dalam mengambil keputusan", hal ini memperlihatkan bahwa BPR se Propinsi Riau belum memadai dalam melibatkan nasabah dalam mengambil keputusan organisasi.

Pada item jalinan kerjasama antar nasabah dengan BPR dengan skor nilai sebesar 2,8397 masuk dalam kategori cukup baik dan ini memberikan makna bahwa sudah cukup terjalin kerjasama antar nasabah dengan BPR, jalinan kerjasama antar nasabah dengan BPR dilakukan dalam bentuk mitra dukungan keuangan usaha, khususnya UMKM pada BPR memberikan komitmen untuk membangun UMKM menjadi lebih berkembang dan bahkan banyak produk BPR yang diprioritaskan kepada perkembangan UMKM dan ini menjadi sebuah usaha nyata dari BPR menjadikan UMKM sebagai basis bisnis mereka.

Kemudian pada item keterlibatan nasabah ke BPR dalam mengambil keputusan dengan skor nilai sebesar 2,5140 masuk dalam kategori cukup baik dan ini memberikan makna bahwa sudah cukup baiknya keterlibatan nasabah ke BPR dalam mengambil keputusan, nasabah memang masih belum dilibatkan secara langsung dalam rangka mengambil keputusan dalam BPR, namun dalam hal usaha untuk menampung saran dari nasabah menjadi prioritas dan pertimbangan dari masukan nasabah dalam membuat jalinan antara BPR dengan nasabah berjalan berkesinambungan.

Selanjutnya pada item kejelasan tanggung jawab petugas BPR kepada nasabahnya dengan skor nilai sebesar 2,8270 masuk dalam kategori cukup baik dan ini memberikan makna bahwa sudah cukup jelasnya tanggung jawab petugas BPR kepada nasabahnya, jelas di sini petugas BPR menjadi orang yang diandalkan dalam menjalankan tugas pelayanan jasa perbankan, petugas berhubungan langsung dengan nasabah dan menjadi orang dipercaya untuk menyampaikan angsuran dan menitipkan angsuran nasabah untuk dibayarkan ke BPR, namun terkadang masih ada persepsi nasabah bahwa petugas bisa saja menggelapkan uang angsuran nasabah. Selama ini petugas BPR cukup mendapatkan kepercayaan dari nasabah, walaupun beberapa nasabah tidak mengandalkan petugas untuk membantu mereka dalam membayarkan angsuran ke BPR.

Dari item kondisi suasana kerja petugas dengan skor nilai sebesar 3.8651 masuk dalam kategori baik dan ini memberikan makna bahwa sudah cukup baiknya kondisi suasana kerja petugas, memang bila dilihat dari suasana kerja di tempat kerja petugas BPR dan dilihat dari kondisi kantor yang digunakan untuk pelayanan kepada nasabah sudah baik dan bahkan dengan ruangan yang ada sudah nyaman dirasakan oleh pihan nasabah dan ini menjadi sebuah usaha BPR memberikan kenyamanan kepada nasabah dalam bertransaksi. Selain itu juga suasana kerja terkesan sangat berbaur dengan keakrabatan antara nasabah dengan petugas, hal ini karena selain petugas sebagian besar adalah pemuda tempatan juga mereka selalu bertemu sehingga ada suasana yang akrab diantara petugas dengan nasabah.

Juga item menyelesaikan masalah yang dihadapi nasabah BPR dengan skor nilai sebesar 2,5674 masuk dalam kategori cukup baik dan ini memberikan makna bahwa sudah cukup baiknya usaha menyelesaikan masalah yang dihadapi nasabah BPR, petugas BPR selalu memberikan solusi dari berbagai persoalan kredit yang dihadapi oleh nasabah dan bahkan padaa kondisi nasabah macet sekalipun, petugas selalu untuk bersikap tenang dan memberikan solusi dari persoalan yang ada. Karena menurut petugas, kondisi ini sudah selalu terjadi, 
sehingga tinggal bagaimana sikap petugas berusaha membuat nasabah tetap berkeinginan melunasi pinjaman mereka.

Terakhir pada item ketuntasan masalah nasabah BPR dengan skor nilai sebesar 2,7888 masuk dalam kategori cukup baik dan ini memberikan makna bahwa sudah cukup adanya ketuntasan masalah nasabah BPR, dirasakan nasabah bahwa masalah yang mereka hadapi tuntas dengan berbagai kondisi, sangat jarang dirasakan nasabah yang enggan membayar hutang dan terkesan menghindar dari petugas dalam berkomunikasi, misalnya saat ditelpon mereka tidak menjawab dan di sms tidak dibalas dan kemudian didatangi ke rumah mereka, mereka tidak ada dan bahkan jarang ditemukan nasabah yang demikian.

Kemudian nasabah yang memberikan tanggapan lebih tinggi dari rata-rata skor total antara lain dimensi Proses interaktif dengan 6 item pertanyaan dinyatakan cukup baik (3,3134), hal ini mengindikasikan bahwa perusahaan selalu dituntut untuk memberikan layanan jasa yang sesuai dengan kebutuhan nasabah dan selalu berupaya meningkatkan layananya agar sesuai dengan kebutuhan nasabah. Nilai yang paling rendah dari dimensi ini adalah pada pertanyaan "Ketersediaan menampung saran nasabah BPR", hal ini memperlihatkan bahwa BPR se Propinsi Riau belum memadai dalam menampung saran nasabah.

Pada Item ketersediaan menerima kritik nasabah BPR dengan skor 3,5216 masuk dalam kategori baik. Ini menunjukkan bahwa BPR sudah bersedia menerima kritik nasabah BPR dan ini juga memberikan gambaran berkenaan dengan kondisi dimana BPR membuka hubungan dengan nasabahnya dan keadaan ini selalu menjadi sebuah perubahan pada BPR. Sebagian BPR yang dikelola oleh pemerintah daerah menerapkan konsep pelayanan prima yang memang diharapkan menjadikan BPR sebagai mitra UMKM dalam melaksanakan usahanya di daerah. Namun sebagian BPR yang dimiliki oleh swasta mereka lebih mengarahkan penyaluran dana BPRnya kepada kelompok-kelompok tertentu dan tentunya hal ini menimbulkan banyak persepsi dan ada ditemukan BPR hanya untuk menyimpan uang pribadinya saja. Keadaan seperti itu ditemukan di lapangan berkaitan dengan hubungan dengan nasabah memang menjadi prioritas karena nasabahnya lebih kepada nasabah yang bersifat istimewa.

Selanjutynya Item ketersediaan menampung saran nasabah BPR dengan skor 2,9059 masuk dalam kategori cukup baik. Ini menunjukkan bahwa sudah adanya ketersediaan menampung saran nasabah BPR, saran dari nasabah berkaitan dengan urusan nasabah mendapatkan pelayanan pada BPR memang sudah ada usaha untuk menampung berbagai hal yang berkaitan dengan pelayanan yang diberikan BPR kepada nasbaah, hal ini selalu mendapatkan perhatian dari direksi dan dalam berbagai kesempatan direksi selalu membicarakan dan memberikan solusi masalah yang terjadi dengan tetap memegang konsep bisnis yang dijalankannya. Masalah efisiensi dan efektifitas usaha BPR menjadi prioritas pengelolaan yang dilakukan. Kemudian juga masalah saran nasabah juga secara langsung dapat diberikan kepada petugas lapangan yang memberikan pelayanan, petugas sudah diberikan arahan kepada direksi untuk memperlakukan nasabah dengan baik dan menampung berbagai saran dari nasabah guna perbaikan pelayanan BPR di depan.

Pada Item bersedia berdiskusi dengan nasabah BPR tentang permaasalahan nya dengan skor 2,9160 masuk dalam kategori cukup baik. Ini menunjukkan bahwa BPR sudah cukup bersedia berdiskusi dengan nasabah BPR tentang permaasalahan nya dapat dijelaskan bahwa adanya usaha petugas BPR mendiskusikan permasalahan pembayaran yang dialami nasabah, usaha membicarakan permasalahan ini dilakukan dengan berbagai solusi dan bahkan win-win solution juga dilakukan. Usaha untuk bagaimana nasabah dapat membayar angsurannya dalam kondisi usaha yang 
masih menurun, dari pihak BPR selalu memberikan perhitungan kembali hutang yang ada dan diperhitungkan dalam jangka waktu yang relative lebih panjang, sehingga jumlah angsuran per bulannya menjadi lebih sedikit dan usaha yang dijalankan akan terus dapat bergerak.

Kemudian pada item menyediakan layanan telfon dalam proses pelayanan BPR dengan skor 3,5623 masuk dalam kategori baik. Ini menunjukkan bahwa BPR sudah bersedia menyediakan layanan telfon dalam proses pelayanan BPR, di lapangan petugas dalam rangka menjalin komunikasi efektif dengan nasabah mereka membuka layanan telfon dan bahkan SMS juga mereka lakukan. Telfon senantiasa aktif dan senantiasa merespon apa yang menjadi pertanyaan nasabah dan bahkan dalam rangka pembayaran angsuran, pada saat jatuh tempo nasabah dapat menelpon petugas untuk menjemput angsuran dan hal ini selalu dilakukan oleh petugas agar terjalin hubungan harmonis antara pihak BPR dengan nasabahnya.

Selanjutnya pada item menyediakan layanan sms banking oleh petugas BPR dengan skor 3,3919 masuk dalam kategori cukup baik. Ini menunjukkan bahwa BPR cukup menyediakan layanan sms banking oleh petugas BPR, layanan sms banking pada sebagian belum diterapkan namun sebagian lainnya layanan sms banking sudah diterapkan. Ini berkaitan dengan masalah relasi yang dibangun antara BPR dengan para nasabahnya, nasabah membutuhkan informasi yang terkini dan melalui sms banking semua informasi dapat disampaikan berkaitan dengan perkembangan sebagai nasabah dan juga memberikan layanan yang dilakukan 24 jam. Sebagian BPR sudah memiliki sistem untuk sms banking sehingga sistem akan bekerja otomatis setiap adanya perubahan data dari nasabah.

Terakhir dari item proses interaktif dengan nasabah yakni mengenai menyediakan layanan antar jempur angsuran kredit oleh petugas BPR dengan skor 3,5827 masuk dalam kategori baik. Ini menunjukkan bahwa BPR sudah menyediakan layanan antar jempur angsuran kredit oleh petugas BPR. Dapat dijelaskan relasi dibangun dengan nasabah dan hubungan ini dijalin dengan layanan antar jemput urusan nasabah dengan BPR, misalnya urusan masalah aplikasi yang digunakan untuk proses pengajuan kredit, pihak BPR senantiasa memberikan waktunya untuk menjemput aplikasi yang sudah diisi dan sudah dilengkapi dan seterusnya untuk urusan pencairan, pihak BPR juga menyediakan waktu kapan saja pihak nasabah ingin mencairkan dananya dan pada urusan pembayaran cicilan urusan ini juga dilayani sampai dimana nasabah berada.

Berdasarkan uraian mengenai kerelasian pemasaran yang dibangun oleh BPR kepada nasabahnya dari dimensi proses interaksi yang dibangun oleh BPR diberikan tanggapan cukup baik dan ini menunjukkan bahwa BPR secara interaksi sudah cukup membangun hubungan dengan nasabahnya dan bahkan ditemukan item tertinggi yakni pada masalah menyediakan layanan antar jemput dalam membangun hubungan dengan nasabahnya. Sedangkan item terendah adalah pada masalah sarana untuk menampung saran, dimana hal ini memang masih perlu mendapatkan perhatian.

Juga dimensi Hubungan pelanggan dengan 6 item pertanyaan dinyatakan cukup baik $(3,1650)$, hal ini mengindikasikan bahwa perusahaan selalu dituntut untuk menjalin hubungan yang baik dengan nasabah dan selalu berupaya menjalin hubungan jangka panjang dengan nasabah. Nilai yang paling rendah dari dimensi ini adalah pada pertanyaan "Menjaga hubungan harmonis dengan nasabah BPR", hal ini memperlihatkan bahwa BPR se Propinsi Riau belum memadai dalam menjaga hubungan harmonis dengan nasabah.

Pada item membangun jalinan komunikasi kepada nasabah BPR dengan skor jawaban responden sebesar 3,6005 masuk dalam kategori baik, yang bermakna bahwa kerelasian pemasaran dilihat dari 
item sudah membangun jalinan komunikasi kepada nasabah BPR, jalinan komunikasi yang bangun BPR kepada nasabahnya berhubungan dengan bagaimana BPR, kemampuan BPR dalam menjalin komunikasi lebih dikarenakan strategi BPR dalam merekrut karyawan, karyawan lebih diutamakan pemuda tempatan, hal ini membuat jalinan komunikasi antara BPR dengan masyarakat tempat menjadi lebih mudah dan tanpa disadari bahwa pemuda yang menjadi karyawan sudah mensosialisasikan produk BPR kepada masyarakat. Masyarakat akan mudah memberikan kepercayaan kepada BPR pada saat salah satu dari anggota masyarakat mereka ikut bergabung di dalam perusahaan mereka.

Kemudian item menyampaikan informasi yang akurat oleh petugas BPR dengan skor jawaban responden sebesar 3,5751 masuk dalam kategori baik, yang bermakna bahwa kerelasian pemasaran dilihat dari item sudah menyampaikan informasi yang akurat oleh petugas BPR, dijelaskan kepada nasabah bahwa akurasi dari penyampaian informasi menjadi salah satu bagian penting, sebagai contoh akurasi dalam hal menentukan batas waktu pembayaran dan sms yang diberikan dalam rangka memastikan waktu pembayaran angsuran sudah sampai. Hal ini menjadi sebuah komunikasi yang efektif disampaikan dan tepat dalam masalah waktu penyampaian. Data dan informasi nasabah menjadi basis dalam menyampaikan informasi. Pada BPR dalam rangka melaksanakan sistem informasi manajemen operasionalisasi dari BPR itu sendiri menggunakan tenaga operator dan tenaga operatornya memiliki data yang lengkap dari nasabahnya.

Selain itu juga pada item menjelaskan proses kerja oleh petugas BPR kepada nasabah BPR dengan skor jawaban responden sebesar 2,9720 masuk dalam kategori cukup baik, yang bermakna bahwa kerelasian pemasaran dilihat dari item sudah menjelaskan proses kerja oleh petugas BPR kepada nasabah BPR, dalam melaksanakan kegiatan pemasarannya dan juga membangun kerelasian pemasaran maka pihak BPR telah membuat sebuah prosedur proses kerja yang menjadi acuan bagi dari petugas dalam melaksanakan kegiatan pelayanannya, maupun dari nasabah dalam menilai kinerja atau proses kerja yang dilaluinya baik dalam proses pengajuan kredit hingga proses pembayaran angsuran, Hal ini terus dilakukan dan menjadi standar dalam pelayanannya di lapangan sehingga diharapkan memberikan nilai kepada nasabah.

Pada item menjelaskan batas layanan yang diberikan petugas BPR dengan skor jawaban responden sebesar 3,5598 masuk dalam kategori baik, yang bermakna bahwa kerelasian pemasaran dilihat dari item sudah menjelaskan batas layanan yang diberikan petugas BPR, bagi nasabah pelayanan yang diberikan BPR kepada mereka merupakan pelayanan jasa yang memiliki harga, dimana harga sangat ditentukan dengan batas kemampuan pelayanan yang diberikan, sehingga dari itu pihak BPR sudah memberikan penjelasan dengan baik berkenaan dengan batas layanan yang mereka miliki dan tinggal bagaimana nasabah menyikapi kondisi tersebut.

Selanjutnya pada item menjalin hubungan pelanggan yang berkesinambungan dengan skor jawaban responden sebesar 2.6489 masuk dalam kategori cukup baik, yang bermakna bahwa kerelasian pemasaran dilihat dari item sudah menjalin hubungan pelanggan yang berkesinambungan, nasabah merupakan bagian penting dalam kesinambungan bisnis BPR, melalui berbagai upaya yang dilakukan pihak BPR untuk bagaimana nasabah tetap loyal dan percaya kepada BPR selalu dilakukan, misalnya dengan cara memberikan informasi berkaitan dengan bunga kredit yang ditawarkan kepada nasabah dan juga adanya produkproduk baru yang dikeluarkan BPR dan sesuai dengan kebutuhan nasabah dan bahkan adanya perlakuan yang istimewa bagi nasabah potensial yang dapat 
mendukung perkembangan BPR. Memang dilihat selama ini BPR memiliki pelanggan yang loyal, dimana pelanggan menganggap kebutuhan keuangan dan permodalan untuk usahanya dapat didukung dengan bermitra kepada BPR.

Terakhir pada item menjaga hubungan harmonis dengan nasabah BPR dengan skor jawaban responden sebesar 2.6336 masuk dalam kategori cukup baik, yang bermakna bahwa kerelasian pemasaran dilihat dari item sudah menjaga hubungan harmonis dengan nasabah BPR, usaha yang dilakukan dari pihak BPR dalam rangka menjaga hubungan yang harmonis menjadi sebuah usaha nyata, dimana melalui usaha pendekatan dan jalinan komunikasi yang dijalin secara berkesinambungan serta memberikan berbagai perhatian terhadap kendala yang dihadapi nasabah dan memberikan solusi dari permasalahan yang nasabah hadapi menjadi sebuah usaha yang dilakukan BPR. BPR selalu memberikan yang terbaik dalam rangka membuat nasabah senang dan mau terus menggunakan jasa perbankan tersebut.

Berdasarkan uraian mengenai hubungan pelanggan yang merupakan bagian dari dimensi kerelasian marketing, maka dapat dijelaskan sudah cukup baiknya usaha yang dilakukan BPR dalam membangunan kerelasian marketing dan bahkan usaha yang paling baik adalah dengan membangun jalinan komunikasi dengan masyarakat setempat, melalui rekrutmen karyawan yang merupakan pemuda setempat sehingga komunikasi dapat diterapkan dengan lebih efektif. Namun masih ada kelemahan dalam hal membuat jalinan kepada masyarakat ini dapat berkesinambungan, karena beberapa nasabah hanya mampu sekali saja melakukan transaksi kreditnya ke BPR dan untuk menjaga hubungan harmonis ini menjadi sebuah persoalan yang tersendiri dihadapi oleh BPR.

Dari uraian mengenai interdepence berkaitan dengan kerelasian marketing, maka dapat diketahui sudah cukup baiknya interdependence yang bangun oleh BPR kepada nasabahnya dengan nilai yang paling tinggi adalah usaha BPR membangun keakraban dalam kondisi suasana kerja petugas dengan nasabah yang terbangun, walaupun dirasakan pada item belum melibatkan nasabah dalam mengambil keputusan dan bahkan ada sebagian masalah nasabah yang belum mampu dituntaskan oleh petugas berkaitan dengan kredit yang mereka dapatkan melalui BPR. Hal ini menjadi sebuah usaha membangun hubungan mitra dengan nasabah.

$$
\text { Rekapitulasi hasil jawaban }
$$

responden mengenai Kerelasian Pemasaran memiliki rata-rata 3,1262 dan standar deviasi 0,9220 dinyatakan termasuk kategori cukup baik, hal ini mengindikasikan bahwa BPR se Propinsi Riau, sangat bervariatif, dimana katagorinya dari kerelasian pemsaran jasa tidak baik menuju sangat baik. Oleh karena itu masih perlu adanya upaya peningkatan kerelasian pemasaran yang lebih baik lagi dan lebih merata.

Kondsi variabel kerelasian pemasaran BPR di Propinsi Riau dalam kategori cukup baik, lebih disebabkan oleh kurangnya ketersediaan sarana menampung saran nasabah BPR, kurangnya kesediaan berdiskusi dengan nasabah BPR tentang permaasalahannya, kurangnya penjelaan proses kerja oleh petugas BPR kepada nasabah BPR, kurang terjalin hubungan dengan pelanggan yang berkesinambungan, kurang terjaga hubungan harmonis dengan pelanggan BPR, kurang terjalin kerjasama antar pelanggan dengan BPR, kurang mempertimbangkan masukan pelanggan ke BPR dalam mengambil keputusan, kurang jelas tanggung jawab petugas BPR kepada nasabahnya, kurangnya kemampuan menyelesaikan masalah yang dihadapi nasabah BPR, kurang tuntas dalam penyelesaian masalah nasabah BPR.

Apabila dikaitkan dengan profil responden khususnya masalah pendidikan, dimana dengan didominasi oleh pendidikan SMA dan bahkan ada $29 \%$ berpendidikan sarjana membuat BPR perlu mempertimbangkan dan membangun kerelasian pelanggan sehingga menambah 
hubungan yang erat dalam memberikan pelayanan kredit.

Upaya yang dapat dilakukan dalam membina kerelasian pemasaran produk BPR dengan cara menyediakan sarana untuk menampung saran nasabah, kemudian berdiskusi dengan nasabah, juga memberikan penjelasan proses kerja dan prosedur pada BPR, serta upaya membangun hubungan yang lebih dekat dengan nasabah yakni melalui penyediaan sistem informasi online. Kemudian dari sisi petugas BPR dalam membangun hubungan dengan pelanggan maka perlu meningkatkan rasa tanggung jawab, mengatasi masalah nasabah secara tuntas dengan cara memberikan pelatihan kepada petugas.

\section{SIMPULAN}

Dari uraian di atas, maka dapat ditarik kesimpulan bahwa BPR di Kota Pekanbaru, sangat bervariatif, dimana katagorinya dari kerelasian pemsaran jasa tidak baik menuju sangat baik. Oleh karena itu masih perlu adanya upaya peningkatan kerelasian pemasaran yang lebih baik lagi dan lebih merata.

Upaya yang dapat dilakukan dalam membina kerelasian pemasaran produk BPR dengan cara menyediakan sarana untuk menampung saran nasabah, kemudian berdiskusi dengan nasabah, juga memberikan penjelasan proses kerja dan prosedur pada BPR, serta upaya membangun hubungan yang lebih dekat dengan nasabah yakni melalui penyediaan sistem informasi online. Kemudian dari sisi petugas BPR dalam membangun hubungan dengan pelanggan maka perlu meningkatkan rasa tanggung jawab, mengatasi masalah nasabah secara tuntas dengan cara memberikan pelatihan kepada petugas.

\section{DAFTAR RUJUKAN}

Alma, Buchari. 2014. Manajemen Pemasaran dan Pemasaran Jasa. Bandung: Alfabeta.
Chan, Syafruddin. 2003. Relationship Marketing: Inovasi Pemasaran yang Membuat. Pelanggan Bertekuk Lutut, Cetakan Kedua, Penerbit Gramedia. Jakarta.

Ebert dan Griffin, 2009, Customer behavior, International Edition

Fandy Tjiptono, 2000, Manajemen Jasa, Penerbit Andi Yogyakarta

Gareth Jones and Mary Mathew, 2009, Organizational Theory, Design and Change, 5th Edition (Delhi : Dorling Kindersley, 2009)

Kisworo, 2013, BPR Harus Jadi "Penjaga Rumah" Ekonomi Nasional, Infobank, Jakarta.

Kotler and Keller, 2016, Marketing Management Edisi 12, Jilid 1, Global Edition.Pearson Prentice. Hall.

Kusmayadi, Tatang. 2007. Pengaruh Relationship Quality Terhadap Loyalitas Nasabah Tabungan. Skripsi. STIE STAN Indonesia Mandiri.

Lovelock. C, 2010, Pemasaran Jasa. Erlangga, Jakarta

Lupiyoadi, Hamdani. 2006. Manajemen Pemasaran Jasa, Edisi Kedua. Penerbit Salemba Empat. Jakarta.

BPS, 2016, Riau dalam Angka, Pekanbaru.

Rhenald Kasali, 2007, Membidik Pasar Indonesia, STP. Jakarta : Gramedia.

Tandjung, J.W., 2004, Marketing Management: Pendekatan Pada 
Nilai-nila. Pelanggan, Edisi Kedua, Jakarta.

Tjiptono dan GregoriusChandra, 2005, Manajemen Kualitas Jasa,. Yogyakarta. ANDI. , 2014, Pemasaran Jasa, Andi Offset, Yogyakarta.

Undang-Undang Dasar 1945 pasal 33 tentang perekonomian

Undang-Undang Nomor 21 Tahun 2011 tentang Otoritas Jasa Keuangan (Lembaran Negara Republik Indonesia Tahun 2011 Nomor 111, Tambahan Lembaran Negara Republik Indonesia Nomor 5253)

Peraturan Otoritas Jasa Keuangan Nomor 20/POJK.03/2014 tentang Bank Perkreditan Rakyat

Permendagri No. 94 Tahun 2007, tentang Pengelolaan Bank Perkreditan Rakyat Milik Pemerintah Daerah.

Diana Angelica dan Ria Cahyani, 2012, Pemasaran Dasar-Dasar : Pendekatan Manajerial Global. Buku 2. Edisi 16. Salemba Empat. Jakarta.

Imron, Much. and Arianto, Dwi Agung Nugroho and Wibowo, Purwo Adi (2011) Analisis Pengaruh Orientasi Produk Dan Orientasi Pasar Terhadap Kinerja Museum. Semantik 2011. pp. 47-53. ISSN 979-26-0255-0

Isnadi, Didik (2005) Analisis Pengaruh Customer Relationship Marketing Terhadap Nilai Nasabah Dan Keunggulan Produk Dalam Meningkatkan Kepuasan Dan Loyalitas Nasabah (Studi Kasus: Pada Bank BRI Kantor Cabang Pekalongan). Masters thesis,
Program Pascasarjana Universitas Diponegoro.

Parasuraman. 2001. The Behaviorial Consequenses of Service Quality, Jurnal of. Marketing. Vol 60.

Putra. Adi. (2009). Pengaruh Kualitas Pelayanan Terhadap Kinerja Kerelasian Nasabah. Jurnal Ekonomi Bisnis. 14(2). 151-160.

Tatang Suhidayat, (2014) pengaruh bauran pemasaran jasa dan kualitas pelayanan terhadap nilai pelanggan dan kepercayaan pelanggan implikasinya pada kepuasan pelanggan danloyalitas pelanggan (Survey pada Nasabah Bank Perkreditan Rakyat di Kota/ Kabupaten Bandung, Kabupaten Bandung Barat, dan Kota Cimahi)

Zeithaml et al, (1996), "Measuring the quality of relationship in customer service: An empirical study", Journal of Marketing. 